\title{
Adaptation of Real Industrial Applications into the Proposed Environmental Emission Standard for Stationary Combustion Systems
}

\author{
K.T. Jayasinghe and D.D. Ananda Namal
}

\begin{abstract}
In this study, the authors have attempted to analyze and emphasize on the impact of the "Proposed Environmental Emission Standard for Stationary Combustion Systems on real industrial applications by collecting data from industry experts who have been directly involved in the implementation of those emission standard with respect to the regulations and limitations that have been defined, industrial impacts, instrumentations, pre-facility requirement and external interferences. This study, however, does not discuss policy implementation practices of different organizations when monitoring the emission levels of stationary combustion systems.
\end{abstract}

The strong recommendations given in this study are based on performance analysis and comparisons of 225 industrial stationary combustion systems that included categories such as thermal power plants, industrial boilers, thermic fluid heaters, incinerators, cupolas/ blast furnaces/coke ovens/basic oxygen furnaces/electric (induction \& arc) furnaces and standby generators mentioned in the proposed environmental emission standard. In addition to plant performance, feedback received from different sectors and data related to emission standards implemented and practiced in 13 Asian countries were also considered.

The recommendations given in this study emphasize on the special areas that need to be reconsidered before implementing this proposed stationary source emission standard. The areas highlighted are bio mass combustion systems, standby diesel generators, incinerators and various categories of furnaces, kilns, ovens etc.

The outcomes of this study will therefore be important and useful when implementing the proposed emission standard in terms of plant categorization, capacity ranges, reference oxygen levels, normalizing conditions, emission limits, system behaviors, standard test methods, requirement of precise and accurate instrumentation etc. Finally, this study expects to provide a reliable, convenient and effective stationary sources emission standard for the benefit of regulatory bodies, industries, instruments \& equipment suppliers, monitoring organizations etc.

Keywords: Particulate Matter, Smoke Opacity, Isokinetic, Ringelman, Transmissivity, ThermicFluid, Electro Static Precipitator

\section{Introduction}

During the last 10 year period, due to the rapid development of energy and industrial sectors, the use of fossil fuel and bio mass in Sri Lanka for electricity generation and other industrial applications has increased by $8 \%$ [SLSEA Energy Balance 2014]. With the increase of the fuel consumption, the relative quantities of emissions released to the environment also will increase. Toxic gases $\left(\mathrm{Pb}, \mathrm{Cl}_{2}\right)$, noxious gases $\left(\mathrm{SO}_{x}, \mathrm{NO}_{\mathrm{X}}\right)$, greenhouse gases $\left(\mathrm{CO}_{2}, \mathrm{O}_{3}\right)$, unburned gases $\left(\mathrm{CO}, \mathrm{C}_{\mathrm{X}} \mathrm{H}_{\mathrm{Y}}\right)$ and Particulate Matter (PM) are the most common types of emissions. These emissions can adversely affect, in various ways, human health and the environment

Although a set of recommended standards has been introduced as a general guideline to industrialists under "Section 32 of National Environmental Act No. 47 of 1980" as amended

by Acts 56 of 1988 and 53 of 2000 [1], those standards are not being strictly practiced by the responsible parties due to several factors such as the failure on the part of authorities concerned to define plant categorizations and specify emission limits in the standard, lack of monitoring facilities and instrumentation etc. Regulatory bodies have proposed a stationary source emission standard by amending the existing in active standard.

Eng. K.T.Jayasinghe, C.Eng., MSc (Energy), MIE(Sri Lanka), Head of the Department \& Research Fellow, National Engineering Research \& Development Centre (NERDC), 2P/17B, Industrial Estate, Ekala, Ja-Ela.

Email: jayasinghe69@yahoo.com

Eng. D.D.Ananda Namal, C.Eng., MSc (Energy), MIE(Sri Lanka), Director General, National Engineering Research \& Development Centre (NERDC), 2P/17B, Industrial Estate, Ekala, Ja-Ela.Email:tilla@nerdc.lk 
This proposed standard is still at the reviewing/formulating stage and the regulatory bodies require feedback from plant manufacturers, industries, monitoring organizations, experts etc., to make it acceptable to the relevant sectors before it becomes legal, enforceable and mandatory. However, when implementing and putting into practice such regulations in real applications, it is found that there are contradictions in the regulations improvements.

This proposed emission standard has been prepared based on emission data available for the period from 2000 to 2008. Emission monitoring during that period has been based on local emission standard that prevailed at that time and has focused on reducing the fuel consumption of combustion systems rather than on reducing the emissions. Furthermore, PM monitoring had not been in place during that period. Moreover, combustion systems like bio mass fired power plants/steam boilers, coal fired electricity generation plants etc., had not been very popular during that period. During the last three or four years after the implementation of the proposed emission standard, the emission levels of almost all combustion systems including domestic cupolas, melting furnaces, bakery ovens etc., have been monitored to obtain emission reports. Monitoring organizations have strengthened their monitoring capacities by purchasing standardized instrumentation, setting up laboratory facilities, applying standard test methods, developing personal skills of their employees in monitoring etc. Therefore, the emission data obtained in the last few years can be much more accurate and practical than the emission data previously obtained and which were used to prepare the proposed emission standard. Thus, the reviewing of the proposed emission standard using emission data that had been recently obtained and standard test methods applicable for different combustion systems might be useful to make the implementation of the standard convenient and practical to policy makers, regulatory bodies, monitoring organizations, industries etc.

\section{Objectives and Methodology}

The main objective of this study was to make suggestions through the following for the implementation of the proposed local emission standard for stationary combustion systems by eliminating its drawbacks, shortcomings, mismatches etc., so that it will be convenient and practical for adoption by the affected groups such as plant manufacturers, industries, regulatory bodies, monitoring organizations etc.

- Reviewing and comparing the proposed standard with the emission standards of 13 countries in the Asian region.

- $\quad$ Interviewing the regulatory bodies that were involved in revising this particular standard and industrial personnel who will be directly involved in the implementation of the standard.

Analysing data obtained from 225 industrial stationary combustion systems during the period from 2013 to 2015 covering each category indicated in the proposed emission standard.

Investigating system variations and effects such as fuel type, operating method, combustion type, plant category etc., of different combustion systems on the standard and reference limits.

- Estimating the deviations of the standard conversion values from measured values in terms of oxygen reference and normalized conditions (pressure and temperature).

- $\quad$ Finding the practical difficulties faced by industries when implementing and maintaining such standards.

\section{Review of the Proposed Emission Standard for Stationary Combustion Systems in Sri Lanka}

The proposed atmospheric emission standard for stationary sources in Sri Lanka comprises of 17 regulations and 3 schedules.

A list of source specific atmospheric emission standards for new or modified stationary sources based on the instrument/equipment type are given in Parts I ,II, III and IV of "Schedule II" . Part I and Part II of "Schedule III" contain a set of general atmospheric emission standards based on the type of the pollutant.

Regulation 3 requires the use of "Schedule III" for stationary sources that have not been included in Schedule II. "[All emissions from stationary sources which have not been specified in Schedule II, shall comply with the pollutant based standards specified in Schedule III of these regulations]". However, this study 
has given more weight to Schedule II than to Schedule III, since most of the stationary combustion systems have been included in Schedule II.

Schedule II of this proposed emission standard mainly focuses on three major areas. Source categorizations and measuring parameters; measurement methods and estimations; and system requirements are the three areas.

\subsection{Source Categorizations and Measuring Parameters}

Considering the type of combustion systems available in the country, stationary combustion systems have been divided into 5 categories, namely thermal power plants; boilers;thermic fluid heaters;incinerators and cupolas, blast furnaces, coke ovens, basic oxygen furnaces, electric (induction \& arc) furnaces etc.

The recommended monitoring parameters and emission levels for each category will depend on plant capacity, and the type of fuel used. The recommended monitoring parameters for different combustion sources are summarized in Table 1.

Table 1 - Recommended monitoring parameters for different combustion systems

\begin{tabular}{|c|c|c|c|c|c|c|c|c|c|}
\hline Plant Category & 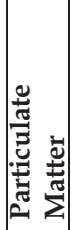 & 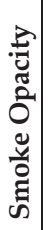 & $\begin{array}{l}x \\
\text { Oڤ }\end{array}$ & $\stackrel{x}{\text { Z }}$ & 0 & $\underset{\widetilde{U}}{\bar{U}}$ & $\stackrel{600}{I}$ & 2 & 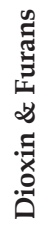 \\
\hline $\begin{array}{l}\text { Thermal Power } \\
\text { Plants- Any Fuel } \\
\text { Except Solid Waste }\end{array}$ & $X$ & $X$ & $X$ & $X$ & - & - & - & - & - \\
\hline $\begin{array}{l}\text { Thermal Power } \\
\text { Plants - Solid Waste } \\
\text { Fuel }\end{array}$ & $X$ & $X$ & $X$ & $X$ & $X$ & $X$ & $X$ & $X$ & - \\
\hline Boilers & $X$ & $\mathrm{X}$ & $\mathrm{X}$ & $X$ & - & - & - & - & - \\
\hline $\begin{array}{ll}\text { Thermic } & \text { Fluid } \\
\text { Heaters } & \end{array}$ & $X$ & $x$ & $X$ & $X$ & - & - & - & - & - \\
\hline Incinerators & $X$ & $X$ & $\mathrm{X}$ & $X$ & $X$ & $X$ & $\mathrm{X}$ & $X$ & $x$ \\
\hline $\begin{array}{l}\text { Cupolas, Furnaces, } \\
\text { Ovens, Kilns }\end{array}$ & $X$ & $X$ & $X$ & $X$ & - & - & - & - & - \\
\hline
\end{tabular}

[Source - Schedule II - Part I to Part V of National Environmental Act No. 47 of 1980]

According to Table 1, monitoring parameters that are common to all of the combustion systems are Particulate Matters (PM), Smoke Opacity, Oxides of Sulphur (SOx) and Oxides of Nitrogen $(\mathrm{NOx})$. In addition to those common parameters, thermal power plants driven by solid waste and waste combustion incinerators require the monitoring of $\mathrm{CO}, \mathrm{HCl}, \mathrm{Hg}, \mathrm{Pb}$ and Dioxins and Furans as well. However in this study, it is the common emission parameters -
PM, Smoke Opacity, $\mathrm{SO}_{x}$ and $\mathrm{NO} x$ of different types of stationary combustion systems that have been taken into consideration.

\subsection{Test Methods and Estimation}

According to Regulation 5, USEPA approved methods or any other method validated with reference to USEPA methods and further approved by the Central Environmental Authority shall be used in the measurement of emissions.

From among the many USEPA test methods that are available to monitor emission parameters, the basic test methods which are commonly used to monitor (discussed in Section 3.1) common parameters and supportive measurements are given in Table 2.

Table 2 - Commonly used USEPA test methods used in the emission measurements of stationary sources

\begin{tabular}{|c|c|}
\hline Testing Parameter / Pollutant & $\begin{array}{l}\text { Estimating } \\
\text { Technique }\end{array}$ \\
\hline $\begin{array}{l}\text { Sample and velocity traverses for } \\
\text { stationary sources [2] }\end{array}$ & USEPA Method 1 \\
\hline $\begin{array}{l}\text { Stack gas velocity and volumetric flow } \\
\text { rate (Type S PITOT tube) [3] }\end{array}$ & USEPA Method 2 \\
\hline $\begin{array}{l}\mathrm{CO}_{2} \text { and } \mathrm{O}_{2} \text { concentrations in } \\
\text { emissions from stationary sources [4] }\end{array}$ & USEPA Method 3A \\
\hline Moisture content in stack gases [6] & USEPA Method 4 \\
\hline $\begin{array}{l}\text { Particulate Matters (PM) emissions } \\
\text { from stationary sources [2] }\end{array}$ & USEPA Method 5 \\
\hline $\begin{array}{l}\mathrm{SO}_{2} \text { emissions from stationary sources } \\
{[4]}\end{array}$ & USEPA Method 6 \\
\hline $\begin{array}{lll}\text { NOx emissions } & \text { from stationary } \\
\text { sources [4] } & & \\
\end{array}$ & USEPA Method 7 \\
\hline $\begin{array}{l}\text { Visual determination of opacity of } \\
\text { emissions from stationary sources }\end{array}$ & USEPA Method 9 \\
\hline $\begin{array}{l}\mathrm{CO} \text { emissions from stationary sources } \\
\text { [4] }\end{array}$ & USEPA Method 10 \\
\hline
\end{tabular}

[Source -Water \& Environmental Technology Section II ASTM 2006]

The parameters that are monitored using USEPA test methods have to be converted into "Dry Basis", "Normalized Conditions" (Standard Temperature and Pressure) and "Reference Oxygen Levels" in order to bring data monitored under different conditions into a common standard base. The guidelines for such standard and reference conversions that have been discussed in Regulations 6, 7 and 8 of this proposed standard are as given below.

[Regulation 6]:- Any parameter relating to the concentration of any stationary source emission measured shall be converted into dry basis.

[Regulation 7]: - Any stationary source emission shall be converted into a Normal Condition such as $0^{\circ} \mathrm{C}$ and $760 \mathrm{~mm} \mathrm{Hg}$. 
- $\quad$ [Regulation 8]:- Any emission parameter measured in relation to stationary source emissions shall be corrected for the relevant reference oxygen level.

\subsection{System Requirements and Limitations}

The system requirements of this proposed standard have been given in order to control toxic gases; especially $\mathrm{SO}_{2}$ and $\mathrm{NO}_{x}$. The key factors discussed under system requirements are given below.

[Regulation 11]:- In any case, except for combustion sources with a gross heat input less than 0.62 MW, the stack (chimney) height shall not be less than $20 \mathrm{~m}$.

- [Regulation 12]: - In case of power plants, $\mathrm{SO}_{2}$ shall be controlled by fuel quality and stack height, if $\mathrm{SO}_{2}$ emission levels have not been specified in the standards.

[Regulation 13]: - Emissions from crematoriums shall be controlled by emission reduction utilities incorporated into the stack of the crematorium.

[Regulation 14]: - Dioxin and Furan emissions from incinerators shall be controlled by maintaining their temperatures between $1100^{\circ} \mathrm{C}$ and $1250^{\circ} \mathrm{C}$ and their retention times in the secondary chamber between 2-3 seconds.

\subsection{Analysis of the Effects of Normalized Conditions on the Measurement of Emission Limits}

According to Regulation 7, all emission concentrations measured have to be converted into normal conditions of $0^{\circ} \mathrm{C}$ and $760 \mathrm{~mm} \mathrm{Hg}$ (1.0 atm.) using the equation

$$
\mathrm{Cn}=\mathrm{Cs} \times(\mathrm{Pn} \times \mathrm{Ts} / \mathrm{Ps} \times \mathrm{Tn})
$$

where, " $\mathrm{C}$ ", " $\mathrm{P}$ " and " $\mathrm{T}$ " refer to the concentration, temperature and pressure respectively. " $n$ " and " $s$ " refer to the normal and measured conditions of each emission parameter.

The standard and plant operating pressure ratio (i.e. Pn/Ps) will not have a heavy impact on converted values, since the standard and plant operating pressure levels are not much different (Based on practice, Pn/Ps is found to be closely equal to 1.0). Then, this equation can be simplified as,

$$
\mathrm{Cn}=\mathrm{Cs} \times(\mathrm{Ts} / \mathrm{Tn})
$$

Accordingly, the conversion factor Ts/Tn, will affect the standard converted values, since the normalized temperature will be considerably different from the emission gas temperature.
The conversion factors for different temperatures are given in Table A 1 in Appendix A.

The measured value has to be multiplied by the factor Ts/Tn to obtain normalized conditions and the multiplying factor will vary from 1.25 to 5.75 for stack temperatures ranging from $75^{\circ} \mathrm{C}$ to $1300^{\circ} \mathrm{C}$

\subsection{Analysis of the Effects of the Reference Oxygen Percentage on the Measurement of Emission Limits}

According to Regulation 8, all measured concentrations have to be converted into the reference oxygen level using

$$
\mathrm{E}_{\mathrm{r}}=\mathrm{E}_{\mathrm{m}} \times\left[\left(20.9-\mathrm{O}_{2} \text { ref. }\right) /\left(20.9-\mathrm{O}_{2} \mathrm{~m}\right)\right]
$$

where, " $E$ " refers to the emission concentration and "ref" and " $\mathrm{m}$ " refer respectively to the reference and measured values of each parameter. According to Schedule VIII of this proposed standard, the reference oxygen levels defined for oil fired and solid fuel fired combustion systems are $3 \%$ and $6 \%$ respectively. In addition to those two reference levels, a reference oxygen level of $10 \%$ is given for waste combustion incinerators. The conversion factors for different reference levels are given in Table A2 in Appendix A.

\section{Review of Emission Standards of the Countries in the Region}

This section discusses and compares the proposed emission standard of Sri Lanka with the emission standardsof13 selected Asian countries, namely Bangladesh, Bhutan, Cambodia, China, Hong Kong, India, Indonesia, Malaysia, Pakistan, Philippines, Singapore, Thailand and Vietnam. However, the additional information given in those standards which however have not been stated in the proposed emission standard of Sri Lanka have not been considered.

\subsection{Comparison of "Pollutant Based" Methods [Schedule III]}

It is not an easy task to make comparisons between the pollutant based standards given in the proposed emission standard with those given in the emission standards of the selected countries since many countries have not clearly defined the pollutant based standard and the general emission standard separately with some countries mixing up instrument/equipment based emission standards with pollutant based standards. For example, the PM emission limits of power plants in Bangladesh have been 
included in the general emission standard and fuel based $\mathrm{NO}_{x}$ emission limits in Pakistan have also been included in the general emission standard. The summarized data of the pollutant based methods of the selected countries are given in Table A - 3 in Appendix A.

The general emission standards practiced in Bhutan, Indonesia, Philippine, Singapore and Vietnam are quite similar to those given in the proposed emission standard of Sri Lanka. However, the emission limits enforced in those countries except in Singapore, are higher than the emission limits proposed for Sri Lanka. Each country has presented normalized values (standard temperature and pressure), but has however, not defined the reference oxygen levels.

\subsection{Comparison of "Instrument/Equipment Based" Methods [Schedule II]}

The detailed comparison of the emission limits specified for different combustion systems in the emission standards of the regional countries are given in Table A-4 to Table A-11 in Appendix A. When comparing those data, it is revealed that the definitions given to plant types, plant capacities, fuel types, emission parameters, reference levels, standard conditions etc., are different from country to country, fuel to fuel, plant to plant etc. Furthermore, the way stationary sources emission standards are presented is different from country to country. However, plant categorization and the way of presenting such standards in Thailand are comparatively similar to those of the proposed standard.

Some countries like Bangladesh, Bhutan, Pakistan, Philippines, and Singapore have defined only the general emission standard for each category of plants. China has focused on implementing their emission standard only for coal processing equipment instead of defining it for different industrial plants since China is using coal as a major fuel. Cambodia, Indonesia, Malaysia, Singapore and Vietnam have focused on several emission parameters except common parameters such as $\mathrm{PM}, \mathrm{SO}_{2}$ and NOx, for their emission standards for combustion systems. India and Singapore have presented a general emission standard for their stationary combustion systems with several special plant/process definitions.

For normalized conditions, Hong Kong and Singapore have used $0^{\circ} \mathrm{C}$ temperature and 1.0 atm. pressure. Indonesia and Thailand have used $25^{\circ} \mathrm{C}$ temperature and $1.0 \mathrm{~atm}$. pressure as normalized conditions. Although other countries have not indicated the specific temperature and pressure values, those countries have also used normalized units $(\mathrm{N})$ to express emission limits.

Hong Kong, Indonesia and Thailand have set the oxygen reference level based on the fuel type or combustion system or sometimes even on both. However, China and India have used it only for cement plant and bagasse fired boilers respectively. The reference oxygen levels given for Sri Lanka are lower than the values of other countries given for similar types of fuel or combustion systems.

\section{Instrumentation}

The most common and critical emission parameter- Particulate Matter (PM) - given for each category of combustion systems of the proposed emission standard has been monitored using "USEPA Test Method 5".

The basic principles, measurement techniques, standard conditions, system requirements, instrument features etc., are not included and discussed in this study as those can be reviewed through the commonly available standard documents.

In general, two methods for determining gaseous components, namely extractive sampling method and non-extractive sampling method are being practiced. Out of those two methods, extractive sampling method is more common.

The location of sampling points that will monitor gaseous concentrations is not as critical as that for monitoring PM, since the variation of the velocity profiles does not affect the homogeneity of the gaseous concentration. This means that proximity to bends, branches, obstructions by fans and dampers is less important. However, sampling after the dilution of air has to be avoided. Therefore, the monitoring of gaseous parameters is convenient and can be implemented in many types of combustion systems, since they do not require any special and expensive pre-facility arrangements.

The standard instrumentation used to monitor PM and other gaseous parameters are illustrated in Figure 1. 


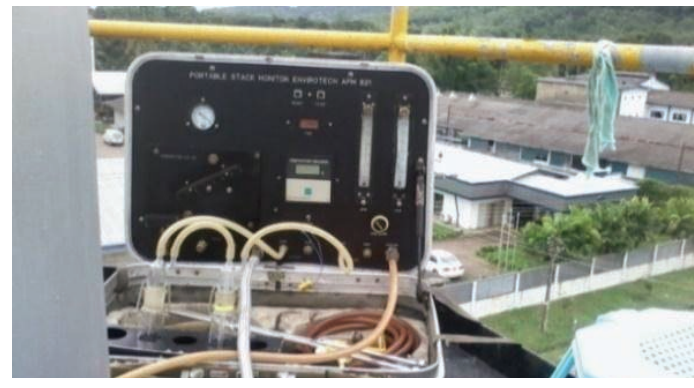

Figure 1 - Standard Instrument Kit used to monitor PM levels in flue gas [9]

The emission parameters of the contents of flue gas such as Oxygen $\left(\mathrm{O}_{2}\right)$, SulphurDioxides $\left(\mathrm{SO}_{2}\right)$, Nitric Oxides $(\mathrm{NOx})$ and Carbon Monoxide (CO) were monitored using electro chemical sensors attached to gas analysers. Carbon Dioxide $\left(\mathrm{CO}_{2}\right)$ was monitored using "Infra-Red (IR)" laser beam test method. The basic components used to monitor gaseous parameters are illustrated in Figure 2.

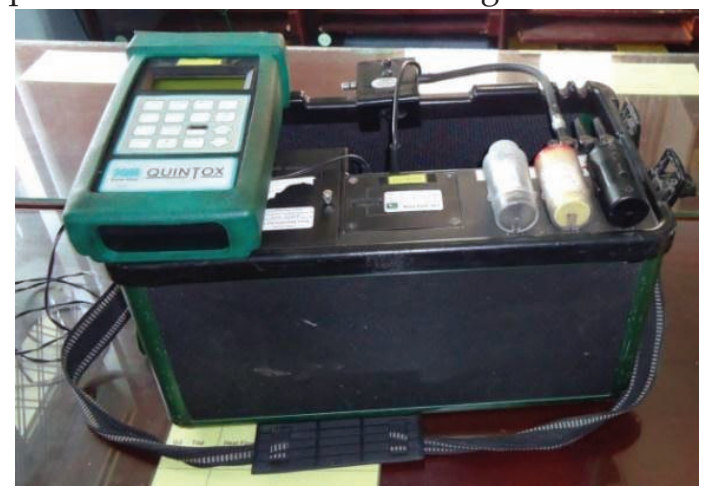

Figure 2 - Standard Instrument Kit used to monitor Dioxins and other gaseous components of Flue Gas [8]

\section{Analysis of Local Emission Data of Different Combustion Systems}

The emission test reports of stationary combustion systems obtained by the National Engineering Research \& Development Centre during the period from 2013 to 2015 were considered in this study. The sample size was 225 which comprised of each category of combustion systems that were being operated. However, emission data obtained at intervals (quarterly or by - annually or annually) from the same combustion system (industry)during the time period considered were taken as separate data sets. The number of combustion systems considered for each group was based on the number of combustion systems available under the particular category (each category by numbers). Accordingly, the number of boilers, thermic heaters which used different fuel types etc., that were tested was higher than the number of power plants, incinerators etc., tested.
However, the combustion systems considered were not grouped based on the capacity ranges defined in the proposed standard due to the complexity of analysis and non-availability of combustion systems in certain capacity ranges. The details of the samples selected from different stationary combustion systems are given in Table 3.

Table 3 - Number of samples selected from different stationary combustion systems

\begin{tabular}{|c|l|c|}
\hline No & \multicolumn{1}{|c|}{ Plant Type } & Total \\
\hline 1 & Fossil Fuel Power Plants & 26 \\
\hline 2 & Bio Mass Power Plants & 9 \\
\hline 3 & Oil Fired Steam Boilers & 12 \\
\hline 4 & Bio Mass Fired Steam Boilers & 89 \\
\hline 5 & Oil Fired Thermic Heaters & 2 \\
\hline 6 & Bio Mass Fired Thermic Heaters & 30 \\
\hline 7 & Furnaces/ Kilns/ Dryers & 28 \\
\hline 8 & Incinerators & 4 \\
\hline 9 & Diesel Generators & 25 \\
\hline \multicolumn{2}{|c|}{ Total } & $\mathbf{2 2 5}$ \\
\hline
\end{tabular}

The temperatures that were measured, analysed and summarised and the percentage range of the oxygen content in the flue gas of each type of combustion systems are given in Table A -12and Table A-13 respectively. In addition to those measured values, PM levels estimated and converted to reference values of each category of combustion systems are given in Table A- 14. The data analysis pertaining to individual combustion systems is discussed in the section that follows.

\subsection{Fossil Fuel Fired Power Plants}

Twenty-six sets of emission data related to fossil fuel fired power plants of different capacities were considered. Diesel fired power plants were not considered, since they have not been in operation during the past three years.

According to Table A - 12, the measured flue gas temperatures of $35 \%$ of power plants have exceeded $300^{\circ} \mathrm{C}$ and the temperatures of $58 \%$ of the power plants have been in the range $150^{\circ} \mathrm{C}-$ $200^{\circ} \mathrm{C}$. Hence, emission levels when converted into normalized values will be increased by a factor of 1.5 to more than 2.0timesof the actual measured emission limits [Ref. Table A - 1].

According to Table A - 13, none of the oil fired power plants has recorded oxygen content below $10.0 \%$ in flue gas. Sixty-five per cent have an oxygen content exceeding $15 \%$ and in the balance $35 \%$, it is in the range $10 \%-15 \%$. 
According to Table A - 14, 62.0\% of the measured PM levels are less than $150 \mathrm{mg} / \mathrm{Nm}^{3}$ and the balance $38 \%$ have exceeded the accepted PM limits of $150 \mathrm{mg} / \mathrm{Nm}^{3}$. However, when those measured values are converted into $3 \%$ reference oxygen level, the PM emission values of a majority (81\%) of oil fired power plants have exceeded the emission limits given in the standard.

\subsection{Bio Mass Fired Power Plants}

Emission data of 9 sets of bio mass power plants of different capacities were considered. Three of these bio mass fired power plants had flue gas cleaning systems incorporated with Electro Static Precipitators (ESP), and bag filters. In addition to the data of those power plants, data of one paddy husk fired and one palm husk fired power plant were also considered. The paddy husk fired power plant had no emission control system. The flue gas cleaning systems of all other power plants are incorporated with $\mathrm{APH}$, cyclone separators, wet scrubbers etc.

According to Table A - 1, the measured values of flue gas temperature of all of the power plants are less than $200^{\circ} \mathrm{C}$. Hence, the normalized converted emission levels may not have a high impact on the emission levels measured.

According to Table A - 13, none of the power plants has recorded oxygen content less than $6 \%$ in flue gas. Fifty-six per cent have oxygen contents in the $10 \%-15 \%$ range and the remaining $44 \%$ share the oxygen content equally between $6 \%-10 \%$ and above $15 \%$.

According to Table A - 14, all PM emission values measured are less than $200 \mathrm{mg} / \mathrm{Nm}^{3}$. However, when those measured values are converted into the $6 \%$ reference oxygen level, $11 \%$ of bio mass fired power plants exceed the emission limits given in the standard.

\subsection{Oil Fired Steam Boilers}

Twelve oil fired steam boilers were considered in this study.

According to Table A - 12, the flue gas temperatures measured in $66 \%$ of the oil fired boilers are in the range $150^{\circ} \mathrm{C}-200^{\circ} \mathrm{C}$ and the temperatures in the balance $34 \%$ have been equally shared between the e ranges $100^{\circ} \mathrm{C}-$ $150^{\circ} \mathrm{C}$ and $200^{\circ} \mathrm{C}-250^{\circ} \mathrm{C}$. Hence, the normalized converted emission levels will be 1.5 times to more than 2.0 times the actual measured emission limits.[Ref. Table A - 1].
According to Table A - 13, in 50\% of the oil fired boilers, the measured oxygen content in flue gas is in the range $6 \%-10 \%$. The percentage of oil fired steam boilers that had oxygen ranges $0 \%$ $3 \%$ and $3 \%-6 \%$ are $17 \%$ and $33 \%$ respectively. None of the boilers has recorded in flue gas an oxygen content exceeding $10 \%$.

According to Table A- 14, 75\% of the measured PM emission levels are above $100 \mathrm{mg} / \mathrm{Nm}^{3}$ and the balance $25 \%$ are less than $100 \mathrm{mg} / \mathrm{Nm}^{3}$. When those measured values are converted into $3 \%$ reference oxygen level, the PM levels of $92 \%$ of the oil fired steam boilers exceed the emission limits given in the standard. (limit of capacity $>2$ tons of steam $/ \mathrm{hr} .=100 \mathrm{mg} / \mathrm{Nm}^{3}$ ).

\subsection{Bio Mass Fired Steam Boilers}

Eighty-nine bio mass fired steam boilers were considered, since this type of boilers siwidely used and popular among the industries.

According to Table A - 12, the measured flue gas temperature of $47 \%$ of the bio mass fired boilers is less than $100^{\circ} \mathrm{C}$ and in $35 \%$ of the boilers it is in the $100^{\circ} \mathrm{C}-150^{\circ} \mathrm{Crange}$. The balance $18 \%$ have recorded measured flue gas temperatures over $150^{\circ} \mathrm{C}$. Hence, the normalized converted emission levels will be 1.5 times to more than2.0 times the actual measured emission limits[Ref. Table A - 1].

According to Table A - 13, none of the bio mass fired steam boilers has recorded in flue gas an oxygen level below $3 \%$ and only $1 \%$ has recorded oxygen levels in the range 3\%-6\%. A majority of $52 \%$ have oxygen contents between $10 \%$ and $15 \%$ and $30 \%$ have recorded flue gas oxygen content above $15 \%$.

According to Table A - 14, a majority(75\%) of the PM emission levels measured are above 100 $\mathrm{mg} / \mathrm{Nm}^{3}$ and the balance $25 \%$ are less than 100 $\mathrm{mg} / \mathrm{Nm}^{3}$. When those measured values are converted into the 3\% reference oxygen level, PM levels of a majority of the bio mass fired steam boilers $(92 \%)$ exceed the emission limits given in the standard. (The steam generating capacities $>2$ tons of steam $/$ hr emission limit= $100 \mathrm{mg} / \mathrm{Nm}^{3}$ ).

\subsection{Oil Fired Thermic Heaters}

Only the standard emission tests that were carried out on two numbers of oil fired thermic heaters were considered in this study, since emission monitoring facilities such as platforms, climbing ladders etc., are not available in oil fired thermic heaters. 
According to lable A - 12, the tlue gas temperatures of $50 \%$ of the oil fired thermic heaters are in the $1500^{\circ} \mathrm{C}-200^{\circ} \mathrm{C}$ range and the balance $50 \%$ have their temperatures in the $250^{\circ} \mathrm{C}-300^{\circ} \mathrm{C}$ range. Hence, the normalized emission levels will be increased to more than 2.0 times the actual measured emission limits[Ref. Table A - 1.0].

According to Table A - 13, the measured oxygen content of flue gas of one thermic heater was in the range $0 \%-3 \%$ and that of the other thermic heater was in the range $3 \%-6 \%$.

According to Table A - 14, the measured PM emission levels of all thermic heaters were below $100 \mathrm{mg} / \mathrm{Nm}^{3}$ and when those were converted into $3 \%$ reference oxygen levels, they are found to be in the range $100 \mathrm{mg} / \mathrm{Nm}^{3}$ to 150 $\mathrm{mg} / \mathrm{Nm}^{3}$.

\subsection{Bio Mass Fired Thermic Heaters}

Thirty data sets of bio mass fired thermic fluid heaters were considered in this study.

According to Table A - 12, the flue gas temperature measured in $37 \%$ of the bio mass fired thermic heaters are in the range $100^{\circ} \mathrm{C}-$ $150^{\circ} \mathrm{C}$ and that of $27 \%$ of the heaters are in the range $150^{\circ} \mathrm{C}-200^{\circ} \mathrm{C}$. Furthermore, $13 \%$ of the thermic heaters have recorded a flue gas temperature exceeding $200^{\circ} \mathrm{C}$. Hence, the normalized emission levels will be increased to 1.5 to over 2.0 times the actual measured emission limits[Ref. Table A - 1].

According to Table A - 13, none of the bio mass fired thermic heaters has recorded a measured oxygen level below 3\% which is similar to the case of bio mass fired steam boilers. Only 3\% have recorded an oxygen level in the range $3 \%$ $6 \%$. A majority, i.e., $47 \%$, have oxygen contents in the range $10 \%-15 \%$ as is the case with bio mass fired steam boilers and $27 \%$ have recorded in flue gas oxygen content above $15 \%$. According to Table A - 14, a majority $((97 \%)$ of the measured PM emission levels are below 100 $\mathrm{mg} / \mathrm{Nm}^{3}$. When those measured values are converted into the $6 \%$ reference oxygen level, the PM levels of a majority, i.e., $83 \%$, of the bio mass fired thermic heaters are less than 150 $\mathrm{mg} / \mathrm{Nm}^{3}$ in value and those of the other heaters have exceeded the limits.

\subsection{Cupolas, Blast Furnaces, Coke Ovens, Basic Oxygen Furnaces and Electric (induction \& arc) Furnaces}

Combustion systems under this category can be divided into two groups, namely 'specific fuel detined combustion systems' and 'tuel not defined combustion systems'. Whereas glass kilns, cupolas, tile kilns etc., are included under defined fuel category combustion systems, melting furnaces, induction furnaces, galvanizing baths etc., are included under nondefined fuel category combustion systems.

Twenty-eight data sets of different types of combustion systems in this category were considered in this study

According to Table A - 12, the measured flue gas temperatures have large variations. Eleven per cent of the combustion systems have recorded temperatures over $300^{\circ} \mathrm{C}$ while $39 \%$ have recorded temperatures below $50^{\circ} \mathrm{C}$. However, none of the combustion systems has recorded a temperature in the range $200^{\circ} \mathrm{C}$ to $300^{\circ} \mathrm{C}$. Those variations might be due to plant types and the nature of the system arrangements.

According to Table A - 13, measured flue gas oxygen contents of a majority, i.e., $75 \%$, are above $15 \%$. The balance $25 \%$ has temperatures in the range $10 \%-15 \%$. Hence, the converted emission levels of a majority of furnaces will be increased to more than 2 times the actual measured emission limits.

According to Table A - 14, the measured PM emission levels of a majority, i.e., of $88 \%$, are less than $100 \mathrm{mg} / \mathrm{Nm}^{3}$. However, when those values are converted into the reference oxygen level, 68\% exceed the PM emission limits given in the proposed emission standard

\subsection{Incinerators}

Many incinerators (batch type) that are being used in the country have not been maintained up to the required standards. The emission monitoring of this type of incinerators is very difficult, since black smoke comes out from them during the first few minutes after they are started. However, a few incinerators used in industries engaged in food processing and livestock processing have been maintained satisfactorily. Therefore, the monitoring of PM emissions is limited for the well-maintained incinerators and only 4 such incinerators were selected for this study.

According to Table A - 12, the flue gas temperatures of $50 \%$ of the incinerators are between $150{ }^{\circ} \mathrm{C}$ and $200^{\circ} \mathrm{C}$ and the temperatures of the balance $50 \%$ are more than $300^{\circ} \mathrm{C}$. Hence, the actual PM emission limit has increased by over 2 times when normalized and it will have 
a heavy impact on the actual measured emission limits[Ref. Table A - 1].

According to Table A - 13, none of the incinerators has recorded flue gas oxygen content less than $10.0 \%$. A majority, i.e., 75\%, have recorded measured flue gas oxygen content over $15 \%$ and the balance had it in the range of $10 \%-15 \%$. Hence, the converted emission levels of a majority of incinerators will be increased to more than 2 times the actual measured emission limits.

According to Table A - 14, the PM emission levels of $75 \%$ of the incinerators are less than $100 \mathrm{mg} / \mathrm{Nm}^{3}$. However, when those are converted into reference oxygen levels, the PM emission levels of all of the incinerators exceed the PM emission limits stated in the proposed emission standard $\left[100 \mathrm{mg} / \mathrm{Nm}^{3}\right.$ for capacities $>1$ ton/hr.].

\subsection{Diesel Generators}

In general, it is difficult to monitor the PM levels of standby generators since the standard dimensions of diesel generators tacks are outside the PM monitoring instrument ranges and test methods. Therefore in this study, the measurements of only gaseous parameters of 25 diesel generators were considered.

According to Table A - 12, the flue gas temperatures of a majority of generators, i.e., $64 \%$, are over $300^{\circ} \mathrm{C}$ and that of the balance are in the range $100^{\circ} \mathrm{C}$ to $200^{\circ} \mathrm{C}$.

According to Table A - 13, none of the generators has recorded flue gas oxygen content below $3.0 \%$. A majority, i.e., 52\%, have recorded a flue gas oxygen content in the range $10 \%-15 \%$ and in $36 \%$ of the generators the value is more than $15 \%$. It was in the range $6 \%-10 \%$ in the balance $12 \%$.

\section{Discussion and Recommendations}

The recommendations made in this study are based on the estimations, performance analysis and comparisons of data collected from different industries covering each category of combustion systems highlighted in the proposed stationary source emission standard. In addition to those plant performances, emission standards of 13 selected Asian countries that have been reviewed were also considered. The special areas that were focused in this study for recommendations are related to the feedback received from different sectors during implementation. Therefore, the recommendations given for individual combustion systems might be helptul in obtaining a reliable, convenient and effective stationary sources emission standard.

\subsection{Oil Fired Thermal Power Plants}

When the regional emission standards are compared with the emission levels measured and the reference levels, it becomes necessary to reconsider the reference oxygen levels given in the proposed emission standard for oil fired power plants. Based on the data obtained, the recommended reference oxygen level for oil fired power plants is $7 \%$ which is the oxygen reference level practiced in Thailand.

Furthermore, normalized values are needed to be reconsidered, especially for gaseous conversions, since the flue gas temperatures of oil fired power plants are comparatively high.

\subsection{Bio Mass Fired Thermal Power Plants}

The proposed reference oxygen level $(6 \%)$ of bio mass power plants can be accepted for plants having flue gas cleaning systems with ESP and bag filters. However, it is necessary to reconsider the reference oxygen levels of lower capacity (kW range) bio mass fired power plants having wet scrubbers, wet bottoms etc., since the actual measured oxygen content in the flue gas of this type of power plants is above $10 \%$. According to data obtained in this study, the recommended reference oxygen level should be $10 \%$.

\subsection{Coal Fired Thermal Power Plants}

The emission limits proposed for coal fired power plants are similar to the emission limits proposed for oil fired power plants. It is assumed that those reference considerations might be due to the non-availability of the statistical data of coal fired power plants in the country, since coal fired power plants were set up in the country only recently.

When considering the regional emission standard stipulated for coal fired thermal power plants, emission limits given in the proposed emission standard are found to be quite similar to the emission limits specified in Indonesia. The reference oxygen level specified in Thailand for coal fired power plants is $7 \%$.

The emission data of coal fired power plants are not available to enable the comparison of emission limits. Therefore, it is recommended to implement the emission limits given for coal fired power plants until the real emission data and plant performance are obtained. Then, revisions can be made in the future, if any unexpected deviations are presented in the 
reterence oxygen level and normalized conditions.

\subsection{Natural Gas/ Naphtha/ Municipal Solid Waste Fired Thermal Power Plants}

This study considered only Naphtha fired thermal power plants under this category since other types of thermal power plants are not locally available.

None of the regional country emission standards are available for Naphtha fired thermal power plants to compare them with the emission limits given in the proposed emission standard. However, when the emission limits given under oil and coal fired thermal power plants are compared, it is revealed that Naphtha fired power plants have lower emission limits for the same reference oxygen level (3\%).

By considering the emission data of Naphtha fired power plants that were measured, it is recommended to reconsider the lower emission limits given to Naphtha fired power plants in the proposed emission standard.

\subsection{Standby Diesel Generators}

The proposed emission standard provides guidelines to control $\mathrm{PM}, \mathrm{SO} x$ and $\mathrm{NO}_{\mathrm{x}}$ emissions of standby generators of higher capacities, by maintaining a minimum stack height of $20 \mathrm{~m}$ and fuel quality. Usually, standby generators are not incorporated with tall stacks. Most of the standby generators depending on their capacity have silencers that are only $6^{\prime \prime}-8^{\prime \prime}$ in diameter and $1^{\prime}-5^{\prime}$ in length. Furthermore, it is practically impossible to extend or introduce $20 \mathrm{~m}$ long chimneys to standby generators, since such modifications will directly affect plant performance [Ref. Fig. 3].

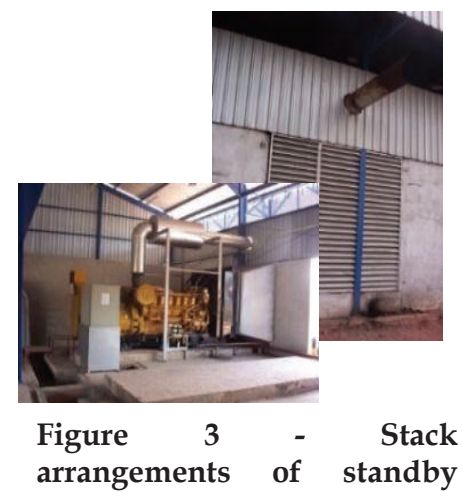

In many local industries, diesel generators are used only for emergency purposes (during island wide electricity failures). Hence, the emissions released from diesel generators to the environment are comparatively less, because their average operating times and related fuel consumptions are less. In this regard, the proposed emission standard has to consider the monthly operating period or power generating capacity rather than the emission limits.

Even though pre-facilities are available to monitor PMs, it is not possible to conduct standard tests due to mismatches that exist between instrumentation (Pitot tubes, nozzles, filter holders etc.) and small stack diameters.

Furthermore, the maintenance of the quality of fuel is the total responsibility of the fuel supplier. The buyers or plant owners are unable to do anything in that regard. Therefore, Regulation 12 given in the proposed emission standard needs reviewing.

In view of the above, it is recommended to monitor monthly operating hours and generating powers to estimate gaseous emissions (based on theoretical estimations) of the diesel generators. Furthermore, it is necessary to reconsider in this proposed emission standard, the stack height defined for higher capacity generators in Regulation 11.

The monitoring of the opacity levels of shorter stacks of standby diesel generators can be implemented. However, it is recommended to confirm the given opacity level $(10 \%)$ of the standby generators only after a proper study.

\subsection{General Considerations for Thermal Power Plants}

In general, thermal power plants are incorporated with either gas turbines or steam turbines or sometimes even with both. The required heat for electricity generation is supplied through a high pressure boiler and the combustion takes place (firing chamber available) inside this boiler. Therefore, some countries have included power generating equipment under boiler category and have not considered them separately under power plants, for example, the coal fired power generating equipment in China. Such considerations are more realistic, since emission limits are directly related to the steam generating capacity rather than to the overall plant performance and power generating capacity. In this regard, it is recommended to include thermal power generating equipment under the boiler category. Then, it will be possible to enforce common emission limits. 


\subsection{Uil Fired Steam Boilers}

Oil fired steam boilers are commonly used as combustion systems in industries to meet their thermal energy demands. Almost all combustion systems in this category are incorporated with mild steel stacks having diameters ranging from 8 " to 24 " and heights ranging from 15 feet to 40 feet. Some stacks have been directly extended through the boiler house roof top and the others have been extended using branch connections between the boilers and the stacks. Therefore, it is practically impossible to extend most of the stacks to meet the standard requirements of gaseous emission controlling and introduce pre-facility requirements for PM monitoring[Ref. Fig.4]

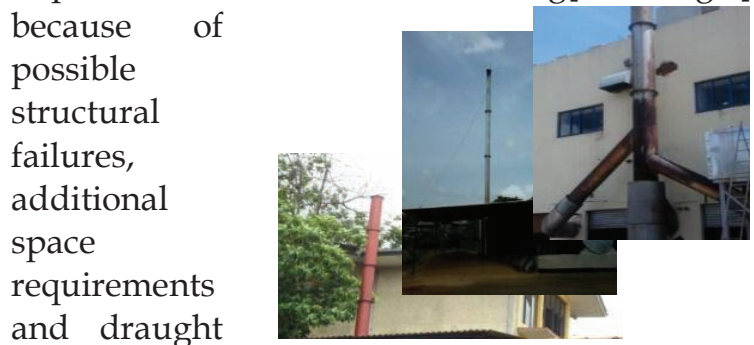

effects etc.

In addition to

Figure 4 - Stack Arrangement of Boilers those difficulties, opacity monitoring using Ringleman method is not practical in many cases due to surrounding obstacles, human errors, stack dimensions etc. Therefore, the only way to monitor exhaust gas emissions of steam boilers is to introduce in place of the existing stacks, new stacks that meet the standard requirements.

When comparing regional emission standards for oil fired boilers, it is found that Sri Lanka has the lowest emission limit as stated in the proposed emission standard at a 3\% reference oxygen level. The reference oxygen levels given in Indonesia and Thailand are $7 \%$ and their emission limits are also high. Based on the outcome of the data analysis, it is proposed to reconsider the oxygen reference level since the reference oxygen converted emission limits in a majority of oil fired boilers are outside the standard limits. The recommended reference oxygen level is $6 \%$ as the measured flue gas oxygen content in a majority of boilers is in the range $6 \%-10 \%$.

The extension of the stack height up to $20 \mathrm{~m}$ or incorporation of flue gas cleaning systems (based on the proposed standard) in oil fired boilers can affect technical design parameters and combustion properties and finally the safety. Therefore, it is recommended to consider the existing oil fired steam boilers that cannot be moditied, as a separate group in the proposed emission standard.

\subsection{Bio Mass Fired Steam Boilers}

Almost all selected boilers in this category are incorporated with air pre-heaters, cyclone separators, wet scrubbers or wet bottoms, water recirculating systems and stacks about 60 feet in height. Such types of boilers have both high capacity Induced Draught (ID) and Forced Draught (FD) blowers in order to maintain the draught pressure throughout the system and to supply the air required for combustion. Therefore, the maintenance of the minimum oxygen content in the flue gas of bio mass fired steam boilers is a huge challenge compared to the maintenance of oxygen content in the flue gas of oil fired steam boilers [Ref. Fig.5].

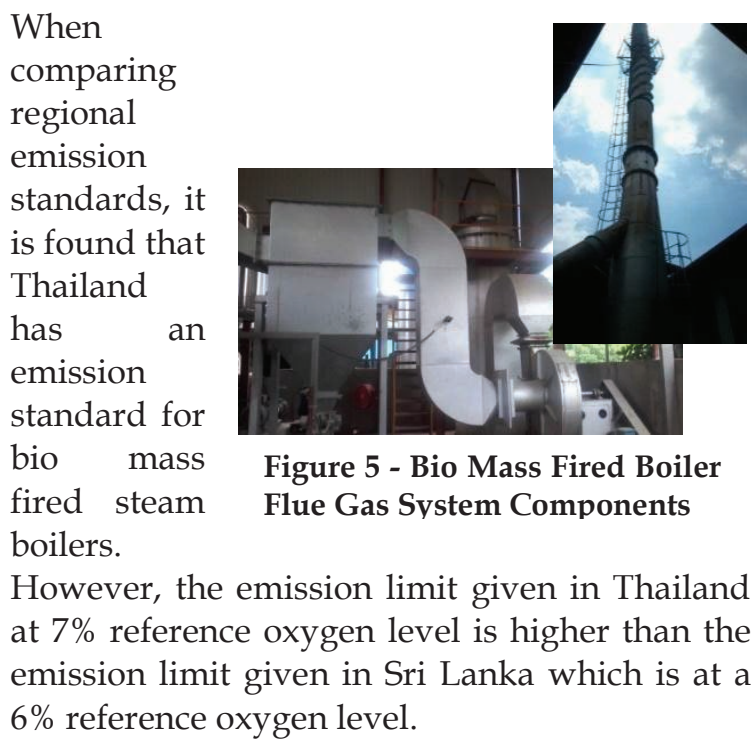

Considering the outcome of the data analysis, it is recommended to reconsider the PM emission limit given in the proposed emission standard for bio mass fired steam boilers based on the PM emission limits given in Thailand. Furthermore, it is recommended to use a $10 \%$ reference oxygen level (instead of $6 \%$ ), since the measured flue gas oxygen content in a majority of bio mass steam boilers has exceeded $6 \%$.

\subsection{Oil Fired Thermic Fluid Heaters}

For many years, oil fired thermic heaters have been popular in industries for high temperature thermal energy applications. The exact number of oil fired thermic heaters currently available in the country cannot be estimated and there are also many oil fired thermic heaters that have been set up a few years back with some of them being already out-dated. In general, emission control mechanisms or waste heat recovery techniques have not been incorporated into oil fired thermic heaters (like oil fired steam 
boilers). The average stack height of oil fired thermic heaters is 40 feet. Emission monitoring facilities such as platforms, climbing ladders etc., are not available with oil fired thermic heaters.

When considering emission standards of the countries in the region, it is found that none of the countries has given separate emission limits for oil fired thermic heaters and therefore no reference data is available to compare them with the emission limits given in the proposed emission standard for oil fired thermic fluid heaters.

The sample size selected in this study is not sufficient to make strong recommendations and it is therefore recommended to further analyse oil fired thermic heater emission levels to confirm the proposed emission limits. However, the under mentioned comments can be made based on similar data of fuel fired steam boilers and performances analysis.

The 3\% reference oxygen level given in the proposed emission standard for oil fired thermic fluid heaters can be accepted. However, if any changes are made to oil fired steam boilers, those changes have to be applied to oil fired thermic fluid heaters as well, since both combustion systems are similar [the only difference being in the operating temperature].

Furthermore, the extension of the stack height up to 60 feet or incorporation of flue gas cleaning systems (based on the proposed standards) will affect technical design parameters and combustion properties and finally the safety. Therefore, it is recommended to consider under a separate group, the existing oil fired thermic fluid heaters that cannot be modified.

\subsection{Bio Mass Fired Thermic Fluid Heaters}

This category of combustion system is almost similar to bio mass fired steam boilers. However those plants are operated at higher temperatures than steam boilers. Waste heat recovery and flue gas cleaning devices in these heaters are almost similar to those of bio mass fired steam boiler systems. Even though thermic heaters have been operated at higher temperature ranges making their stack temperature levels high, they will not affect flue gas emission parameters since flue gas gets cooled when passed through wet bottoms/ water scrubbers.

As for the regional emission standards, it appears that none of the countries has separately mentioned the emission limits for bio mass fired thermic fluid heaters and therefore no reference data is available to compare the emission limits given in the proposed emission standard for oil fired thermic fluid heaters.

However, based on measured and analysed data, it becomes necessary to reconsider the reference oxygen level defined in the proposed emission standard for bio mass fired thermic heaters $(6 \%)$, since the oxygen contents measured in flue gas in a majority of bio mass fired thermic heaters are above $10 \%$.As in the case of bio mass fired steam boilers, the recommended reference oxygen level is $10 \%$.

\subsection{Incinerators}

Waste combustion incinerators are the worst combustion systems found among the different stationary combustion systems discussed in this proposed emission standard. It is because that unlike in other combustion systems, in this type of incinerators not only fuel combustion emissions, but other harmful gaseous substances from waste combustion also are emitted to the atmosphere. Therefore, not only $\mathrm{SO}_{\mathrm{x}}$ and $\mathrm{NO}_{\mathrm{x}}$, but other toxic gases too have to be monitored in the case of these incinerators. [Ref. Table 1]. However, many incinerators have not been incorporated with pre-facility requirements to monitor either PM, opacity or any other gaseous parameters. Furthermore, systems having flue gas cleaning devices (like water scrubbers) with stacks about $20 \mathrm{~m}$ in height are rarely found.

Even though the emission regulations for waste combustion are stricter than those of other combustion systems, it can be seen that non standardized plants (emitting gaseous pollutants) are being operated island wide. This is basically due to non-recommended waste combustion, over charging (waste), employment of unskilled operators, mismatched plant specifications (stack height, retention time, number of burners etc.), and incineration temperatures etc. In addition to those, some stacks are made out of fire bricks and therefore it is not possible to undertake the monitoring of the pre-

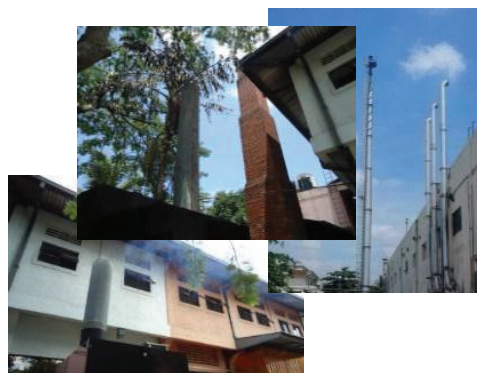

Figure 6 - Stack Arrangement of Incinerators facility, water scrubbing etc.[Ref. Figure 6]. 
This standard also provides guidelines to monitor the secondary chamber temperature of around $1100{ }^{\circ} \mathrm{C}-1250^{\circ} \mathrm{C}$ and the retention time of around 2 - 3 seconds to control Dioxin and Furan emissions. Of the two monitoring parameters, temperature can be monitored using high temperature sensors. However, the type of sensors and instrumentation required is not commonly available. In addition to that, there are no practical methods to ensure that this type of plants will operate under recommended / designed retention times.

Therefore, after considering the above limitations, it can be concluded that the most practical method to control emissions from incinerators is to introduce a water scrubbers to the systems. However, it is not practical to modify the existing incinerators due to the unlimited number of design parameter variations possible. However, permission can be given to purchase or set up new incinerators having water scrubbers, multi chambers, standard stack heights etc.

Thailand has set the PM emission limit at 400 $\mathrm{mg} / \mathrm{Nm}^{3}$ for a $7 \%$ reference oxygen level. This limit is higher than the limit given in the proposed emission standard which is at a $10 \%$ reference oxygen level.

The sample size selected is not sufficient to make strong recommendations and it is proposed to further analyse he incinerator emission levels to confirm the proposed emission limits. However, the under mentioned comments can be made based on practice.

The normalizing emission limits need to be reconsidered, since the flue gas temperatures of incinerators are high. These high temperatures can affect other gaseous conversions more than the PM conversion. Furthermore, it is recommended to reconsider the oxygen reference level, since the measured oxygen content in the flue gas of incinerators is high. In addition to those, it is recommended to address system components, flue gas cleaning arrangements, types of waste burning etc., rather than monitoring the emission data of incinerators.

\subsection{Cupolas, Blast Furnaces, Coke Ovens, Basic Oxygen Furnaces, Electric (Induction \& Arc) Furnaces}

The emission limits given in the proposed standard under cupolas, blast furnaces, coke ovens, basic oxygen furnaces, electric (induction and arc) furnaces etc., can be directly compared with the emission limits given in Thailand.

Based on the data analysis and estimations, the under mentioned comments can be made with regard to this category of combustion systems.

It is recommended to reconsider the kiln separately, since flue gas temperatures of kilns are comparatively higher than those of other plants in this category. Furthermore, it is proposed to reconsider the reference oxygen level considering the oxygen content measured in the flue gas of systems coming under this category, especially the open loop type combustion systems such as continues type furnaces, kilns and batch type open system furnaces like cupolas and melting furnaces [Ref. Figure 7]. In addition to those, more emission allowances should be given to

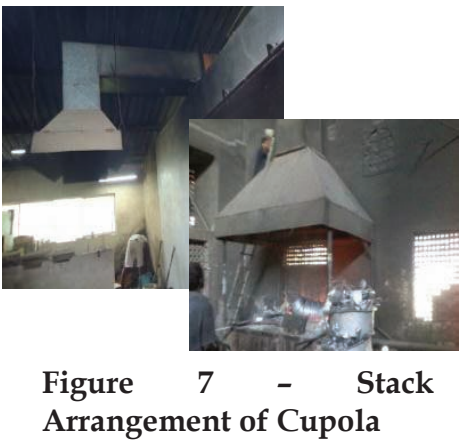
induction furnaces since this type of plants are operated using electricity.

\subsection{Issues Related to Emission Monitoring in Other Types of Stationary Combustion Sources}

This section considers the difficulties encountered in the monitoring of emissions of stationary combustion sources which have not been included in the proposed stationary source emission standard.

Even though Regulation 3requires the emissions of this type of combustion sources to comply with the pollutant based standards specified in Schedule III, there are several contradictions as stated below.

a) Usually, combustion systems included under this category belong to domestic or SMI sectors which have traditional bakery ovens, bricks/tile kilns, lime furnaces, traditional charcoal manufacturing systems, traditional food processing ovens etc. The fuel used in almost all of these combustion systems is bio fuel. Furthermore, many combustion systems are not operated continuously and most of them operate only periodically (according to the requirements). However, the emission parameters and the limits to be monitored as given in Schedule III (even Part 1) are stricter than the parameters and the limits specified for large scale combustion sources mentioned in Schedule III. Therefore, it is recommended to 
consider this type of combustion systems separately.

b) The emissions are released by the above mentioned combustion systems or waste heat recovery furnaces/ovens (e.g. Biscuits manufacturing baking ovens, tobacco barns etc.) as natural draught (there is no forced draught air circulation). Therefore, this type of natural firing systems does not have sufficient flue gas flow rates (velocities) to undergo standard emission tests. In this regard, it is recommended to consider separately, the natural draught firing combustion systems which operate on bio fuel or waste heat, since the amount of emissions released to the atmosphere is less.

c) Some industrial combustion systems cannot be clearly defined as to which category under which they can be included, e.g., traditional air heaters used in the tea industry. They can be included either under the boiler category in Schedule II - Part II, under the furnace category in Schedule II - Part V or under the non-category in Schedule III - Part I. If such type of plants are included under bio mass boiler category, it is necessary to monitor only the PM emission (but they cannot be matched to the capacity, since the output is hot air and not steam). However, if those plants are included under one of the other two categories, they need to be monitored for more emission parameters. Therefore, it is recommended to clearly define this type of traditional/domestic type combustion systems and specify reasonable emission limits for them.

\subsection{Accurate Handling of Sampling (PM)}

The accurate handling and monitoring of collected PM might be an important factor, since the quantity of particles collected for each test is very small. Therefore, even a little variation and impact on the dust samples collected will affect considerably the final test results, since several conversions and estimations have to be adopted. Therefore, this section discusses the importance of accurate monitoring and handling of the particles collected.

According to the results of the study, the weights of almost all the samples collected were either less than $0.0100 \mathrm{mg}$ or were in the range $0.0100 \mathrm{mg}-0.0500 \mathrm{mg}$ and no sample exceeded $0.2000 \mathrm{mg}$ in weight. This indicates the importance of maintaining accuracy when collecting and monitoring PM samples. The factors that affect the accuracy of the measurements are given below. a) Sample collection time duration- More dust particles can be collected, if the colleting time is longer. The accuracy will be reduced, when the sample collecting time is less.

b) Plant operating performance-The samples collected will be different, if the combustion system has not operated continuously during sample collection such as in the case of steam boilers, thermic heaters etc. For this type of systems, more than one sample will have to be collected.

c) Sample collecting filter (Thimbles) handling-The accuracy of the initial weighing of the thimbles is very important. The variation of the weight of a thimble even by a micro gram will have a heavy impact on the final test results.

d) Correct thimble selection-The properties of the thimbles that collect particles can change during sample collection, if the right thimbles for the application concerned have not been selected. When thimbles are exposed to different temperatures, their material properties can change which can affect their weight.

e) Safe handling of the raw thimbles -There is a possibility of foreign particles getting into the samples during their collection, since sample collections are carried out at a certain height above ground level. Therefore, dust free and clean equipment must be used to handle the sampling thimbles.

f) Safe handling of the sampling thimblesThimbles containing collected samples have to be protected until the samples are weighed. Even a small weight change can have a heavy impact on the final test results.

g) Accurate sample processing -The samples collected have to be stored in a moisture and dust free environment until their final weights are confirmed.

h) Accurate weighing of the final sample-The final sample has to be weighed repeatedly until a constant weight is obtained up to4 decimal places on the weight scale.

\section{Conclusion}

This study focused on noncompliance areas and practical inconveniences encountered by different organizations/sectors while implementing and regulating the proposed stationary combustion sources emission standard. The recommendations made in this study are based on the performance analysis and comparisons of 225 industrial stationary 
combustion systems covering each category included in the proposed emission standard.

The data analysis indicates the improvements possible in the areas of plant categorization, normalised and reference oxygen levels, emission limits, applicable test methods etc. Furthermore, the requirements essential to ensure accurate measurements and the use of precise instrumentation in monitoring were also discussed. In addition to those, the deviations of stationary sources emission standards of other countries in the region from the proposed stationary source emission standard were discussed.

The authors believe that the recommendations given in this study which are based on real data analysis, estimations, reviews based on practical and standard industrial data sets are convenient and that they can be easily introduced to the relevant areas of the proposed stationary source emission standard to enable its implementation in more practical, flexible, and convenient ways by the regulatory bodies, industries, instruments and equipment suppliers, monitoring organizations etc.

The recommendations given for individual combustion systems will be useful for reviewing the proposed emission standard to make it more reliable, convenient and effective.

\section{Acknowledgement}

The authors wish to thank the Ministry of Technology and Research for the grant made available to study this important area. We would also wish to thank Eng. Shavindranath Fernando, Chairman, NERDC, for granting permission to publish this paper. We also appreciate the professional inputs given by Dr. (Miss) Sanafica M Yung, Senior Research Scientist, NERDC, and Miss Manjula T Siriwardane, Senior Research Engineer, NERDC by way of editing the paper.

\section{References}

1. National Environmental Act No 47 of 1980-as amended by Acts 56 of 1988 and 53 of 2000 .

2. International Standards; ISO 7935 Stationary Source Emissions - Determinations of the Mass Concentration of Sulphur Dioxide - Performance Characteristics of Automated Measuring Methods.

3. International Standards; ISO 10396 - Stationary Source Emissions - Sampling for the Automated Determination of Gas Concentrations.
4. Sampling Requirements for Stack Emission Monitoring; Environment Agency, Version 4, July 2006. Technical Guide Note (Monitoring) M I.

5. Monitoring of Stack Emissions to Air; Environment Agency Version 4, July 2006. Technical Guide Note (Monitoring) M 2.

6. Proposed Environmental Standards for Stationary Combustion Sources; Central Environmental Authority, Sri Lanka

7. “KM 9106" Flue Gas Analyser Operation Manual, Kane International Limited, Kane House, Swallow field, Welweyn Garden City, Hertfordshire, AL 7 IJG.

8. "ENVIROTECH APM 621" Stack Monitoring Kit Operation Manual, VAYUBODHAN UPKARAN (Pvt.) Ltd. A 292/1, Okla. Industrial Area Phase 1, New Delhi - 110020.

9. Sri Lanka Environment Outlook 2009, Ministry of Environment \& Natural Resource, United Nations Environment Programme.

10. Stationary Combustion Sources Emission Test Reports. National Engineering Research \& Development Centre- 2013-2014.

11. Water \& Environmental Technology. Section II]ASTM 2006. 


\section{APPENDIX A}

Table A 1 - Temperature conversion effects on the measurements

\begin{tabular}{|c|c|c|c|c|c|c|c|c|}
\hline \multicolumn{2}{|c|}{ Temperature (Ts) } & Factor & \multicolumn{2}{|c|}{ Temperature (Ts) } & Factor & \multicolumn{2}{|c|}{ Temperature (Ts) } & Factor \\
\hline$(0 \mathrm{C})$ & $\mathrm{K}$ & Ts/Tn & $(0 \mathrm{C})$ & $\mathbf{K}$ & Ts/Tn & $(0 \mathrm{C})$ & $\mathrm{K}$ & $\mathrm{Ts} / \mathrm{Tn}$ \\
\hline 75 & 348 & 1.27 & 500 & 773 & 2.83 & 925 & 1198 & 4.39 \\
\hline 100 & 373 & 1.37 & 525 & 798 & 2.92 & 950 & 1223 & 4.48 \\
\hline 125 & 398 & 1.46 & 550 & 823 & 3.01 & 975 & 1248 & 4.57 \\
\hline 150 & 423 & 1.55 & 575 & 848 & 3.11 & 1000 & 1273 & 4.66 \\
\hline 175 & 448 & 1.64 & 600 & 873 & 3.20 & 1025 & 1298 & 4.75 \\
\hline 200 & 473 & 1.73 & 625 & 898 & 3.29 & 1050 & 1323 & 4.85 \\
\hline 225 & 498 & 1.82 & 650 & 923 & 3.38 & 1075 & 1348 & 4.94 \\
\hline 250 & 523 & 1.92 & 675 & 948 & 3.47 & 1100 & 1373 & 5.03 \\
\hline 275 & 548 & 2.01 & 700 & 973 & 3.56 & 1125 & 1398 & 5.12 \\
\hline 300 & 573 & 2.10 & 725 & 998 & 3.66 & 1150 & 1423 & 5.21 \\
\hline 325 & 598 & 2.19 & 750 & 1023 & 3.75 & 1175 & 1448 & 5.30 \\
\hline 350 & 623 & 2.28 & 775 & 1048 & 3.84 & 1200 & 1473 & 5.40 \\
\hline 375 & 648 & 2.37 & 800 & 1073 & 3.93 & 1225 & 1498 & 5.49 \\
\hline 400 & 673 & 2.47 & 825 & 1098 & 4.02 & 1250 & 1523 & 5.58 \\
\hline 425 & 698 & 2.56 & 850 & 1123 & 4.11 & 1275 & 1548 & 5.67 \\
\hline 450 & 723 & 2.65 & 875 & 1148 & 4.21 & 1300 & 1573 & 5.76 \\
\hline 475 & 748 & 2.74 & 900 & 1173 & 4.30 & & & \\
\hline
\end{tabular}

Table A 2 - Reference oxygen conversion effects onthe measured values

\begin{tabular}{|c|c|c|c|c|c|c|c|c|c|}
\hline \multirow{2}{*}{$\begin{array}{c}\begin{array}{c}\text { Measured Oxygen } \\
\text { Level }\end{array} \\
\%\end{array}$} & \multicolumn{4}{|c|}{ Reference Oxygen Level } & \multirow{2}{*}{$\begin{array}{c}\text { Measured } \\
\text { Oxygen Level } \\
\%\end{array}$} & \multicolumn{4}{|c|}{ Reference Oxygen Level } \\
\hline & $3 \%$ & $6 \%$ & $10 \%$ & $15 \%$ & & $3 \%$ & $6 \%$ & $10 \%$ & $15 \%$ \\
\hline 3.0 & 1.00 & & & & 12.0 & 2.01 & 1.67 & 1.22 & \\
\hline 3.5 & 1.03 & & & & 12.5 & 2.13 & 1.77 & 1.30 & \\
\hline 4.0 & 1.06 & & & & 13.0 & 2.27 & 1.89 & 1.38 & \\
\hline 4.5 & 1.09 & & & & 13.5 & 2.42 & 2.01 & 1.47 & \\
\hline 5.0 & 1.13 & & & & 14.0 & 2.59 & 2.16 & 1.58 & \\
\hline 5.5 & 1.16 & & & & 14.5 & 2.80 & 2.33 & 1.70 & \\
\hline 6.0 & 1.20 & 1.00 & & & 15.0 & 3.03 & 2.53 & 1.85 & 1.00 \\
\hline 6.5 & 1.24 & 1.03 & & & 15.5 & 3.31 & 2.76 & 2.02 & 1.09 \\
\hline 7.0 & 1.29 & 1.07 & & & 16.0 & 3.65 & 3.04 & 2.22 & 1.20 \\
\hline 7.5 & 1.34 & 1.11 & & & 16.5 & 4.07 & 3.39 & 2.48 & 1.34 \\
\hline 8.0 & 1.39 & 1.16 & & & 17.0 & 4.59 & 3.82 & 2.79 & 1.51 \\
\hline 8.5 & 1.44 & 1.20 & & & 17.5 & 5.26 & 4.38 & 3.21 & 1.74 \\
\hline 9.0 & 1.50 & 1.25 & & & 18.0 & 6.17 & 5.14 & 3.76 & 2.03 \\
\hline 9.5 & 1.57 & 1.31 & & & 18.5 & 7.46 & 6.21 & 4.54 & 2.46 \\
\hline 10.0 & 1.64 & 1.37 & 1.00 & & 19.0 & 9.42 & 7.84 & 5.74 & 3.11 \\
\hline 10.5 & 1.72 & 1.43 & 1.05 & & 19.5 & 12.79 & 10.64 & 7.79 & 4.21 \\
\hline 11.0 & 1.81 & 1.51 & 1.10 & & 20.0 & 19.89 & 16.56 & 12.11 & 6.56 \\
\hline 11.5 & 1.90 & 1.59 & 1.16 & & 20.5 & 44.75 & 37.25 & 27.25 & 14.75 \\
\hline
\end{tabular}

Table A 3- Summary of comparison of data of "Pollutant Based" Methods [Scheduled III] with data of regional countries

\begin{tabular}{|c|c|c|c|c|c|c|c|c|c|c|c|c|c|c|}
\hline Pollutant & $\begin{array}{l}\text { Sri } \\
\text { Lanka }\end{array}$ & $\begin{array}{l}\text { Bangla } \\
\text { desh }\end{array}$ & $\begin{array}{l}\text { Bhuta } \\
\text { n }\end{array}$ & $\begin{array}{l}\text { Cambo } \\
\text { dia }\end{array}$ & China & $\begin{array}{l}\text { Hong } \\
\text { Kong }\end{array}$ & India & $\begin{array}{l}\text { Indon } \\
\text { esia }\end{array}$ & $\begin{array}{l}\text { Malays } \\
\text { ia }\end{array}$ & Pakistan & $\begin{array}{l}\text { Philippin } \\
\text { es }\end{array}$ & $\begin{array}{l}\text { Singa } \\
\text { pore }\end{array}$ & \begin{tabular}{|l|} 
Thail \\
and
\end{tabular} & Viet Nam \\
\hline $\mathrm{PM}\left(\mathrm{mg} / \mathrm{Nm}^{3}\right)$ & 150 & \multirow{5}{*}{ 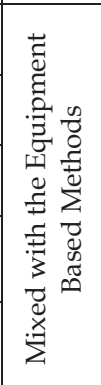 } & \begin{tabular}{|r|}
$300-$ \\
400 \\
\end{tabular} & NI & NA & NA & 150 & 350 & NA & NI & 200 & 100 & 320 & $\begin{array}{l}600[\mathrm{~A}] \\
400[\mathrm{~B}] \\
\end{array}$ \\
\hline Opacity (\%) & 25 & & NI & NI & NA & NA & NI & 35 & NA & 40 & NI & 20 & $\mathrm{NI}$ & NI \\
\hline $\mathrm{CO}\left(\mathrm{mg} / \mathrm{Nm}^{3}\right)$ & 900 & & 5000 & 1000 & NA & NA & $1 \%$ & NI & NA & 800 & 500 & 625 & 690 & $\begin{array}{c}1500[\mathrm{~A}] \\
500[\mathrm{~B}]\end{array}$ \\
\hline $\mathrm{SO}_{2}\left(\mathrm{mg} / \mathrm{Nm}^{3}\right)$ & 1000 & & 1000 & 500 & NA & NA & NI & 800 & NA & 1700 & $\begin{array}{c}1000[\mathrm{~A}] \\
200[\mathrm{~B}]\end{array}$ & 500 & NI & $\begin{array}{c}1500[\mathrm{~A}] \\
500[\mathrm{~B}]\end{array}$ \\
\hline $\mathrm{NO} x\left(\mathrm{mg} / \mathrm{Nm}^{3}\right)$ & 500 & & 470 & 1000 & NA & NA & NI & 1000 & NA & $\begin{array}{l}\text { Fuel } \\
\text { Based }\end{array}$ & $\begin{array}{c}1000[\mathrm{~A}] \\
500[\mathrm{~B}]\end{array}$ & 700 & NI & $\begin{array}{l}2500[\mathrm{~A}] \\
1000[\mathrm{~B}]\end{array}$ \\
\hline
\end{tabular}

A - Existing Plants

B - New Plants

NI - Not Indicated

NA - Not Available

Table A 4 - Comparison of reference oxygen values of oil fired power plants in the selected countries

\begin{tabular}{|c|c|c|c|c|c|c|}
\hline \multirow[b]{2}{*}{ Parameters } & Sri Lanka & Bangladesh & \multicolumn{2}{|c|}{ Hong Kong } & \multicolumn{2}{|c|}{ Thailand } \\
\hline & $\begin{array}{l}\text { Standard Values } \\
\left(\mathrm{O}_{2} \text { Ref. 3\%) }\right.\end{array}$ & $\begin{array}{c}\text { Standard Values } \\
\left(\mathrm{O}_{2} \text { Ref. Not Indicated }\right)\end{array}$ & $\begin{array}{l}\text { Standard Values } \\
\left(\mathrm{O}_{2} \text { Ref. 15\%) }\right.\end{array}$ & $\begin{array}{r}\text { Conversion } \\
\left(\mathrm{O}_{2} \text { Ref. 3\%) }\right.\end{array}$ & $\begin{array}{l}\text { Standard Values } \\
\left(\mathrm{O}_{2} \text { Ref. } 7 \%\right)\end{array}$ & $\begin{array}{l}\text { Conversion } \\
\left(\mathrm{O}_{2} \text { Ref. 3\%) }\right.\end{array}$ \\
\hline $\mathrm{SO}_{2}\left(\mathrm{mg} / \mathrm{Nm}^{3}\right)$ & Not Defined & Not Defined & 290 & 880 & 640 & 800 \\
\hline $\mathrm{NO} \times\left(\mathrm{mg} / \mathrm{Nm}^{3}\right)$ & 450 & 60 & 150 & 455 & 180 & 225 \\
\hline $\mathrm{PM}\left(\mathrm{mg} / \mathrm{Nm}^{3}\right)$ & 150 & 350 & 10 & 30 & 120 & 150 \\
\hline
\end{tabular}


Table A 5 - Comparison of reference oxygen effects of coal fired power plants in the selected countries

\begin{tabular}{|l|c|c|c|c|c|c|}
\hline \multirow{2}{*}{ Parameters } & Sri Lanka & Indonesia & \multicolumn{2}{|c|}{ Hong Kong } & \multicolumn{2}{c|}{ Thailand } \\
\cline { 2 - 7 } & $\begin{array}{c}\text { Standard Values } \\
\left(\mathbf{O}_{2} \text { Ref. 3\%) }\right.\end{array}$ & $\begin{array}{c}\text { Standard Values } \\
(\mathbf{O} \text { 2 Ref. 3\%) }\end{array}$ & $\begin{array}{c}\text { Standard Values } \\
\left(\mathbf{O}_{2} \text { Ref. 6\%) }\right.\end{array}$ & $\begin{array}{c}\text { Conversion } \\
\left(\mathbf{O}_{2} \text { Ref. 3\%) }\right.\end{array}$ & $\begin{array}{c}\text { Standard Values } \\
\left(\mathbf{O}_{2} \text { Ref. 7\%) }\right.\end{array}$ & $\begin{array}{c}\text { Conversion }\left(\mathbf{O}_{2}\right. \\
\text { Ref. 3\%) }\end{array}$ \\
\hline $\mathrm{SO}_{2}\left(\mathbf{m g} / \mathrm{Nm}^{3}\right)$ & 1600 & 750 & 200 & 250 & 2000 & 2500 \\
\hline $\mathrm{NO} \times\left(\mathrm{mg} / \mathrm{Nm}^{3}\right)$ & 650 & 850 & 670 & 800 & 820 & 1000 \\
\hline $\mathrm{PM}\left(\mathrm{mg} / \mathrm{Nm}^{3}\right)$ & 150 & 150 & 50 & 60 & 320 & 400 \\
\hline
\end{tabular}

Table A 6 - Comparison of reference oxygen effects of oil fired steam boilers in the selected countries

\begin{tabular}{|c|c|c|c|c|c|c|c|c|c|c|}
\hline \multirow{3}{*}{ Parameters } & \multirow{3}{*}{$\begin{array}{c}\text { Sri } \\
\text { Lanka }\end{array}$} & $\begin{array}{c}\text { Bangla } \\
\text { desh }\end{array}$ & China & India & \multicolumn{2}{|c|}{ Indonesia } & Pakistan & $\begin{array}{c}\text { Philip } \\
\text { pine }\end{array}$ & \multicolumn{2}{|c|}{ Thailand } \\
\hline & & \multicolumn{3}{|c|}{ Given } & \multirow{2}{*}{$\begin{array}{c}\text { Given } \\
\left(\mathrm{O}_{2}\right. \\
\text { Ref. } 7 \\
\%) \\
\end{array}$} & \multirow{2}{*}{$\begin{array}{c}\text { Conversi } \\
\text { on }\left(\mathrm{O}_{2}\right. \\
\text { Ref. } 3 \%)\end{array}$} & & & \multirow{2}{*}{$\begin{array}{c}\text { Given } \\
\left(\mathrm{O}_{2} \text { Ref. }\right. \\
7 \%)\end{array}$} & \multirow{2}{*}{$\begin{array}{r}\text { Conversion } \\
\text { (O2 Ref. 3\%) }\end{array}$} \\
\hline & & \multicolumn{3}{|c|}{$\left(\mathrm{O}_{2}\right.$ Ref. not indicated $)$} & & & $\begin{array}{r}\mathrm{CO}_{2} \mathrm{R} \\
\text { indi }\end{array}$ & $\begin{array}{l}\text { not } \\
\text { ed) }\end{array}$ & & \\
\hline $\mathrm{SO}_{2}\left(\mathrm{mg} / \mathrm{Nm}^{3}\right)$ & - & 300 & 900 & - & 1400 & 1800 & - & - & 1950 & 2500 \\
\hline $\mathrm{NO} \times\left(\mathrm{mg} / \mathrm{Nm}^{3}\right)$ & - & - & 600 & - & 1200 & 1550 & - & 600 & 570 & 700 \\
\hline $\mathrm{PM}\left(\mathrm{mg} / \mathrm{Nm}^{3}\right)$ & 100 & 300 & 150 & 1200 & 400 & 500 & 300 & 200 & 240 & 300 \\
\hline
\end{tabular}

Table A 7 - Comparison of reference oxygen effects of bio mass fired boilers in the selected countries

\begin{tabular}{|l|c|c|c|}
\hline \multirow{2}{*}{ Parameters } & Sri Lanka & \multicolumn{2}{|c|}{ Thailand } \\
\cline { 2 - 4 } & Given $\left(\mathbf{O}_{2}\right.$ Ref. 6 \%) & Given $\left(\mathbf{O}_{2}\right.$ Ref. 7 \%) & Conversion $\left(\mathbf{O}_{2}\right.$ Ref. 6\%) \\
\hline $\mathrm{SO}_{2}\left(\mathrm{mg} / \mathrm{Nm}^{3}\right)$ & - & 175 & 200 \\
\hline $\mathrm{NO}\left(\mathrm{mg} / \mathrm{Nm}^{3}\right)$ & - & 400 & 400 \\
\hline $\mathrm{PM}\left(\mathrm{mg} / \mathrm{Nm}^{3}\right)$ & 200 & 320 & 350 \\
\hline
\end{tabular}

Table A 8- Comparison of reference oxygen effects of coal fired boilers in the selected countries

\begin{tabular}{|l|c|c|c|c|c|c|c|c|}
\hline \multirow{2}{*}{ Parameters } & Sri Lanka & $\begin{array}{c}\text { Banglad } \\
\text { esh }\end{array}$ & China & Indonesia & Pakistan & $\begin{array}{c}\text { Philipp } \\
\text { ine }\end{array}$ & \multicolumn{3}{|c|}{ Thailand } \\
\cline { 2 - 9 } & $\begin{array}{c}\text { Given } \\
\left(\mathrm{O}_{2} \text { Ref. 3 \%) }\right.\end{array}$ & Given & Given & $\begin{array}{c}\text { Given } \\
\left(\mathrm{O}_{2} \text { Ref. 3 \%) }\right.\end{array}$ & Given & Given & $\begin{array}{c}\text { Given } \\
\left(\mathrm{O}_{2} \text { Ref. 7 \%) }\right)\end{array}$ & $\begin{array}{c}\text { Conversion } \\
\left(\mathbf{O}_{2} \text { Ref. 3\%) }\right.\end{array}$ \\
\hline $\mathrm{SO}_{2}\left(\mathrm{mg} / \mathrm{Nm}^{3}\right)$ & 500 & - & 400 & 750 & & 1000 & 2000 & 2500 \\
\hline $\mathrm{NO} \times\left(\mathrm{mg} / \mathrm{Nm}^{3}\right)$ & 850 & 600 & 900 & 850 & 1200 & 1000 & 800 & 1000 \\
\hline $\mathrm{PM}\left(\mathrm{mg} / \mathrm{Nm}^{3}\right)$ & 150 & 500 & 200 & 150 & 500 & 200 & 320 & 400 \\
\hline
\end{tabular}

Table A9 - Comparison of reference oxygen effects of incinerators in the selected countries

\begin{tabular}{|c|c|c|c|c|}
\hline \begin{tabular}{|c|} 
Rated Output Capacity \\
(MT/hr.)
\end{tabular} & & $\begin{array}{c}\text { Sri Lanka } \\
\left(\mathrm{O}_{2} \text { Ref. } 10 \%\right)\end{array}$ & $\begin{array}{c}\text { Thailand- Given } \\
\left(\mathrm{O}_{2} \text { Ref. } 7 \%\right)\end{array}$ & $\begin{array}{c}\text { Thailand- Converted } \\
\left(\mathrm{O}_{2} \text { Ref. } 10 \%\right)\end{array}$ \\
\hline \multirow{9}{*}{$\mathrm{C}<\mathrm{I}$ MT / hour } & $\mathrm{SO}_{2}\left(\mathrm{mg} / \mathrm{Nm}^{3}\right)$ & 70 & 85 & 70 \\
\hline & $\mathrm{NO}_{x}\left(\mathrm{mg} / \mathrm{Nm}^{3}\right)$ & 400 & 500 & 400 \\
\hline & $\mathrm{PM}\left(\mathrm{mg} / \mathrm{Nm}^{3}\right)$ & $350^{*}$ & 400 & 300 \\
\hline & Smoke Opacity \% & 20 & 20 & 20 \\
\hline & $\mathrm{CO}\left(\mathrm{mg} / \mathrm{Nm}^{3}\right)$ & 50 & - & - \\
\hline & $\mathrm{HCI}\left(\mathrm{mg} / \mathrm{Nm}^{3}\right)$ & 20 & 100 & 75 \\
\hline & Mercury $\left(\mathrm{mg} / \mathrm{Nm}^{3}\right)$ & 0.01 & - & - \\
\hline & Lead $\left(\mathrm{mg} / \mathrm{Nm}^{3}\right)$ & 0.05 & - & - \\
\hline & Dioxin and Furans $\left(\mathrm{mg} / \mathrm{Nm}^{3}\right)$ & $\mathrm{a}$ & - & - \\
\hline \multirow{9}{*}{$\mathrm{C}>2 \mathrm{MT} /$ hour } & $\mathrm{SO}_{2}\left(\mathrm{mg} / \mathrm{Nm}^{3}\right)$ & 70 & 85 & 70 \\
\hline & $\mathrm{NO}_{\mathrm{x}}\left(\mathrm{mg} / \mathrm{Nm}^{3}\right)$ & 300 & 300 & 250 \\
\hline & $\mathrm{PM}\left(\mathrm{mg} / \mathrm{Nm}^{3}\right)$ & 100 & 120 & 100 \\
\hline & Smoke Opacity \% & 10 & 10 & 10 \\
\hline & $\mathrm{CO}\left(\mathrm{mg} / \mathrm{Nm}^{3}\right)$ & 50 & - & - \\
\hline & $\mathrm{HCI}\left(\mathrm{mg} / \mathrm{Nm}^{3}\right)$ & 15 & 10 & 10 \\
\hline & Mercury $\left(\mathrm{mg} / \mathrm{Nm}^{3}\right)$ & 0.001 & - & - \\
\hline & Lead $\left(\mathrm{mg} / \mathrm{Nm}^{3}\right)$ & 0.01 & - & - \\
\hline & Dioxin and Furans $\left(\mathrm{mg} / \mathrm{Nm}^{3}\right)$ & $\mathrm{a}$ & - & - \\
\hline
\end{tabular}

* $350 \mathrm{mg} / \mathrm{Nm}^{3}$ for the plant capacity $<1.0 \mathrm{MT} / \mathrm{hr}$. and $100 \mathrm{mg} / \mathrm{Nm}^{3}$ for the plant capacity $>1.0 \mathrm{MT} / \mathrm{hr}$.

a - Shall be controlled by temperature and retention time as defined in regulation 14 . Reference Condition is $25{ }^{\circ} \mathrm{C}$ at 1 atm. and Oxygen $10 \%$ and dry basis 
Table A 10- Comparison of reference oxygen effects of cupolas, blast furnaces, coke ovens, basic oxygen furnaces, electric (induction \&arc) furnaces in the selected countries

\begin{tabular}{|c|c|c|c|c|c|c|}
\hline Parameters & \multicolumn{2}{|c|}{$\mathrm{SO}_{2}\left(\mathrm{mg} / \mathrm{Nm}^{3}\right)$} & \multicolumn{2}{|c|}{$\mathrm{NO}_{x}\left(\mathrm{mg} / \mathrm{Nm}^{3}\right)$} & \multicolumn{2}{|c|}{$\mathrm{PM}\left(\mathrm{mg} / \mathrm{Nm}^{3}\right)$} \\
\hline Sri Lanka $\left(\mathrm{O}_{2}\right.$ Ref. $\left.6 \%\right)$ & 800 & 800 & 500 & 500 & 150 & 150 \\
\hline Bangladesh & - & - & - & - & 250 & - \\
\hline Cambodia & - & - & - & - & 400 & - \\
\hline Indonesia $\left(\mathrm{O}_{2}\right.$ Ref. $\left.10 \%\right)$ & - & - & - & - & 150 & 205 \\
\hline Indonesia & - & - & - & - & & - \\
\hline Pakistan & - & - & - & - & 500 & - \\
\hline Philippine & - & - & - & - & 150 & - \\
\hline Thailand $\left(\mathrm{O}_{2}\right.$ Ref. $\left.7 \%\right)$ & 2000 & 2150 & 350 & 375 & 120 & 130 \\
\hline Viet Nam & - & - & - & - & 200 & - \\
\hline
\end{tabular}

Table A 11 - Standard conditions and reference oxygen levels of combustion systems

\begin{tabular}{|c|c|c|c|c|}
\hline \multirow{2}{*}{ Country } & \multirow{2}{*}{ Plant Type } & \multicolumn{2}{|c|}{$\begin{array}{l}\text { Standard Conditions } \\
\end{array}$} & \multirow{2}{*}{$\begin{array}{c}\text { Reference } \mathrm{O}_{2} \text { Level } \\
(\%)\end{array}$} \\
\hline & & Temperature $\left({ }^{0} \mathrm{C}\right)$ & Pressure (atm.) & \\
\hline \multirow{4}{*}{ Sri Lanka } & Oil \& Gaseous Fuel & 0 & 1 & 3 \\
\hline & Solid Fuel & 0 & 1 & 6 \\
\hline & Incinerators & 0 & 1 & 10 \\
\hline & Fuel Not Specified & 0 & 1 & 6 \\
\hline China & Cement Industry & $\begin{array}{l}\text { General Units. Value Not } \\
\text { Indicated }\end{array}$ & $\begin{array}{l}\text { General Units. Value Not } \\
\text { Indicated }\end{array}$ & 10 \\
\hline \multirow{3}{*}{ Hong Kong } & Coal Fired Power Plants & \begin{tabular}{|r|r}
0 & \\
\end{tabular} & \begin{tabular}{|l|l}
1 & \\
\end{tabular} & 6 \\
\hline & Gas Fired Power Plants & 0 & 1 & 15 \\
\hline & Oil Fired Power Plants & 0 & 1 & 15 \\
\hline India & Bagasse Fired Boilers & $\begin{array}{l}\text { Normalized Units. Value Not } \\
\text { Indicated }\end{array}$ & $\begin{array}{l}\text { Normalized Units. Value } \\
\text { Not Indicated }\end{array}$ & $12\left[\mathrm{CO}_{2}(\%)\right]$ \\
\hline \multirow{7}{*}{ Indonesia } & Steel Industry & \begin{tabular}{|r|r}
20 \\
\end{tabular} & \begin{tabular}{|c|c}
1 & \\
\end{tabular} & 10 \\
\hline & Coal Fired Power Boilers & 25 & 1 & 3 \\
\hline & Paper Industry Recovery Furnaces & 25 & 1 & 8 \\
\hline & Paper Industry Power Boilers, & 25 & 1 & 7 \\
\hline & Other Facilities & 25 & 1 & 10 \\
\hline & Cement Industry & 25 & 1 & 7 \\
\hline & Other Industries & 25 & 1 & Not Indicated \\
\hline \multirow{6}{*}{ Thailand } & New Power Plants & 25 & 1 & 7 \\
\hline & Municipal Waste Incinerators & 25 & 1 & 7 \\
\hline & Infected Waste Incinerators & 25 & 1 & 7 \\
\hline & Cement Plants & 25 & 1 & 3 \\
\hline & Steel Industry & 25 & 1 & 7 \\
\hline & Any Industrial Combustion & 25 & 1 & 7 \\
\hline
\end{tabular}

Table A 12 - Summary of temperature variations of different combustion systems

\begin{tabular}{|c|c|c|c|c|c|c|c|c|}
\hline \multirow{2}{*}{ Plant Type } & \multicolumn{7}{|c|}{ Measured Temperature } & \multirow{2}{*}{ Total } \\
\hline & $<50$ & $50-100$ & $101-150$ & $151-200$ & $201-250$ & $251-300$ & $>300$ & \\
\hline Fossil Fuel - Power Plants & 0 & 0 & 2 & 15 & 0 & 0 & 9 & 26 \\
\hline$\%$ & 0 & 0 & 8 & 58 & 0 & 0 & 35 & 100 \\
\hline Bio Mass - Power Plants & 0 & 1 & 6 & 2 & 0 & 0 & 0 & 9 \\
\hline$\%$ & 0 & 11 & 67 & 22 & 0 & 0 & 0 & 100 \\
\hline Oil Fired Boilers & 0 & 0 & 2 & 8 & 2 & 0 & 0 & 12 \\
\hline$\%$ & 0 & 0 & 17 & 67 & 17 & 0 & 0 & 100 \\
\hline Bio Mass Boilers & 0 & 42 & 31 & 5 & 8 & 3 & 0 & 89 \\
\hline$\%$ & 0 & 47 & 35 & 6 & 9 & 3 & 0 & 100 \\
\hline Oil Fired Thermic Heaters & 0 & 0 & 0 & 1 & 0 & 1 & 0 & 2 \\
\hline$\%$ & 0 & 0 & 0 & 50 & 0 & 50 & 0 & 100 \\
\hline Bio Mass Thermic Heaters & 0 & 7 & 11 & 8 & 4 & 0 & 0 & 30 \\
\hline$\%$ & 0 & 23 & 37 & 27 & 13 & 0 & 0 & 100 \\
\hline Furnaces/Kilns/Dryers & 11 & 5 & 5 & 4 & 0 & 0 & 3 & 28 \\
\hline$\%$ & 39 & 18 & 18 & 14 & 0 & 0 & 11 & 100 \\
\hline Incinerators & 0 & 0 & 0 & 2 & 0 & 0 & 2 & 4 \\
\hline$\%$ & 0 & 0 & 0 & 50 & 0 & 0 & 50 & 100 \\
\hline Diesel Generators & 0 & 1 & 4 & 4 & 0 & 0 & 16 & 25 \\
\hline$\%$ & 0 & 4 & 16 & 16 & 0 & 0 & 64 & 100 \\
\hline
\end{tabular}


Table A 13 - Summary of measured oxygen content in flue gas of different combustion systems

\begin{tabular}{|c|c|c|c|c|c|c|}
\hline \multirow{2}{*}{ Plant Type } & \multicolumn{6}{|c|}{ Oxygen Content (\%) } \\
\hline & $0-3$ & $3-6$ & $6-10$ & $10-15$ & $>15$ & Total \\
\hline Fossil Fuel Power Plants & & & & 9 & 17 & 26 \\
\hline$\%$ & & & & 35 & 65 & 100 \\
\hline Bio Mass Power Plants & & & 2 & 5 & 2 & 9 \\
\hline$\%$ & & & 22 & 56 & 22 & 100 \\
\hline Oil Fired Boilers & 2 & 4 & 6 & & & 12 \\
\hline$\%$ & 17 & 33 & 50 & & & 100 \\
\hline Bio Mass Boilers & & 1 & 15 & 46 & 27 & 89 \\
\hline$\%$ & & 1 & 17 & 52 & 30 & 100 \\
\hline Oil Fired Thermic Heaters & 1 & 1 & & & & 2 \\
\hline$\%$ & 50 & 50 & & & & 100 \\
\hline Bio Mass Thermic Heaters & & 1 & 7 & 14 & 8 & 30 \\
\hline$\%$ & & 3 & 23 & 47 & 27 & 100 \\
\hline Furnaces/Kilns/Dryers & & & 4 & 3 & 21 & 28 \\
\hline$\%$ & & & 14 & 11 & 75 & 100 \\
\hline Incinerators & & & & 1 & 3 & 4 \\
\hline$\%$ & & & & 25 & 75 & 100 \\
\hline Diesel Generators & & & 3 & 13 & 9 & 25 \\
\hline$\%$ & & & 12 & 52 & 36 & 100 \\
\hline
\end{tabular}

Table A 14 - Summary of measured and reference oxygen converted PM levels of different combustion systems

\begin{tabular}{|c|c|c|c|c|c|c|c|c|c|c|c|}
\hline \multirow[t]{2}{*}{ Plant Type } & \multicolumn{6}{|c|}{ Measured PM Level (mg/Nm³) } & \multicolumn{4}{|c|}{$\begin{array}{l}\text { Reference Converted PM Level } \\
\left(\mathrm{mg} / \mathrm{Nm}^{3}\right)\end{array}$} & \multirow[t]{2}{*}{ Total } \\
\hline & $<25$ & $25-50$ & $50-100$ & $100-150$ & $150-200$ & $>200$ & $<100$ & $100-150$ & $150-200$ & $>200$ & \\
\hline Fossil Fuel Power Plants & 2 & 3 & 3 & 8 & 5 & 5 & 3 & 2 & 1 & 20 & 26 \\
\hline$\%$ & 7 & 12 & 12 & 31 & 19 & 19 & 12 & 8 & 4 & 77 & 100 \\
\hline Bio Mass Power Plants & 7 & 0 & 1 & 1 & 0 & 0 & 0 & 7 & 1 & 1 & 9 \\
\hline$\%$ & 78 & 0 & 11 & 11 & 0 & 0 & 0 & 78 & 11 & 11 & 100 \\
\hline Oil Boilers & 0 & 0 & 3 & 6 & 1 & 2 & 1 & 4 & 4 & 3 & 12 \\
\hline$\%$ & 0 & 0 & 25 & 50 & 8 & 17 & 8 & 33 & 33 & 26 & 100 \\
\hline Bio Mass Boilers & 8 & 18 & 43 & 8 & 4 & 8 & 31 & 24 & 13 & 21 & 89 \\
\hline$\%$ & 9 & 20 & 48 & 9 & 4 & 9 & 35 & 27 & 15 & 24 & 100 \\
\hline Oil Thermic Heaters & 0 & 0 & 2 & 0 & 0 & 0 & 2 & 0 & 0 & 0 & 2 \\
\hline$\%$ & 0 & 0 & 100 & 0 & 0 & 0 & 100 & 0 & 0 & 0 & 100 \\
\hline Bio Mass Thermic Heaters & 9 & 11 & 9 & 1 & 0 & 0 & 19 & 6 & 4 & 1 & 30 \\
\hline$\%$ & 30 & 37 & 30 & 3 & 0 & 0 & 63 & 20 & 13 & 3 & 100 \\
\hline Furnaces/Kilns/Dryers & 11 & 10 & 4 & 1 & 1 & 1 & 4 & 5 & 3 & 16 & 28 \\
\hline$\%$ & 39 & 36 & 14 & 4 & 4 & 4 & 14 & 18 & 11 & 57 & 100 \\
\hline Incinerators & 1 & 1 & 1 & 0 & 1 & & 0 & 1 & 0 & 3 & 4 \\
\hline$\%$ & 25 & 25 & 25 & 0 & 25 & 0 & 0 & 25 & 0 & 75 & 100 \\
\hline Diesel Generators & 0 & 0 & 0 & 0 & 0 & 0 & 0 & 0 & 0 & 0 & 0 \\
\hline$\%$ & 0 & 0 & 0 & 0 & 0 & 0 & 0 & 0 & 0 & 0 & 0 \\
\hline
\end{tabular}

